\title{
BIOCHEMICAL CHARACTERIZATION OF THE ALMONDS OF Hyphaene Guineensis OF PREFECTURE OF POINTE NOIRE IN THE REPUBLIC OF CONGO
}

\author{
J.P.L. Ossoko, J. Enzonga Yoca, Y.Okandza, M.G. Dzondo, M.D. Mvoula Tsieri \\ Laboratory of Processing and Quality of Foods. ENSAF: National School of Agronomy and \\ Forestry (Research) Brazzaville Rep of CONGO.
}

\begin{abstract}
Hyphaene guineensis is one of the Palm trees that grow in the Republic of Congo. Their almonds are high in carbohydrates (41,18\%). The humidity is 37,32\%; The levels of protein, fat and fiber are respectively: 5,64\% 13,51\% and 10.85\%. The ash content is $2.35 \%$. Among the identified ions, there are: phosphorus: $0.18 \%$, iron: 0.06\%, Calcium: $0.44 \%$ and Magnesium: 0.65\%. The calculated energy is 308, 87 $\mathrm{Kcal} / 100 \mathrm{~g}$. The fruits have mass average of $87,88 \mathrm{~g}$.
\end{abstract}

Key words: Hyphaene guineensis, almonds, Palm, characterization.

Cite this Article: J.P.L. Ossoko, J. Enzonga Yoca, Y.Okandza, M.G. Dzondo, M.D. Mvoula Tsieri, Biochemical Characterization of the Almonds of Hyphaene Guineensis of Prefecture of Pointe Noire in the Republic of Congo, International Journal of Advanced Research in Engineering and Technology, 10 (4), 2019, pp 32-39.

$\mathrm{http} / / /$ iaeme.com/Home/issue/IJARET?Volume $=10 \&$ Issue $=4$

\section{INTRODUCTION}

The countries of Central Africa have significant and varied agricultural potential through their Equatorial tropical climate. Unfortunately, this capital is insufficiently exploited and makes the country dependent on food imports, to meet the food needs of their populations.

This dependence is pronounced in the field of fats and proteins.

With the population growth and the requirements for health, quality, life and various industrial applications exploitation of the global botanical reserve orients research new sources of lipids, proteins and carbohydrates high performance or high functionality (nutritional, therapeutic, cosmetic).

In recent years, there has been a renewed interest in non-conventional crops with both potential assets for the development of populations at the local level as the industry [1].

The valorization of the local Palm trees as a source of fat, protein or carbohydrate sometimes takes us to rare specimens that can be investigated. Indeed, Hyphaene guineensis is one of the Palm trees that grow in the wild in the plains of Congo-Brazzaville and has never been as usual culinary applications (oil, used as a source of protein production or carbs,). 
The purpose of our study is to characterize extracted almond of the fruits of this particular palm nuts.

Development in place of these agricultural resources by simple processes particularly well controlled at the local level could achieve this goal of development. These sectors have a significant pool of plant raw materials, leading to products with high added value through the implementation of processing adapted to local technological capabilities.

That's why seventy oleaginous species of the Congo basin, from 35 botanical families were studied; their oil content and composition in fatty acids were determined. Very numerous works have been published on this subject $[2 ; 3 ; 4 ; 5 ; 6 ; 7]$. Despite all this work of valorization of oilseeds in the Congo basin, the study of our Palm does not appear to challenge the scientific community of this area.

In the Congo where agriculture is not a predominant activity, Hyphaene guineensis species not yet had its heyday, or is being investigated. The fact that it grows in the wild, this species can be very useful both on cultural, cosmetic, but also economically in our country. The by-products of Hyphaene guineensis (leaves, stem...) have various uses. Almonds can in particular formed a great asset if you can determine their physicochemical and biochemical characteristics.

This present work has so for general purpose:

Valuation of the species Hyphaene guineensis (in particular its almonds)

\section{MATERIAL AND METHODS}

\subsection{Plant material}

The plant material used for our study was extracted almonds of the coconut Hyphaene guineensis. The harvest of the fruits is done in the Department of Pointe Noire, precisely along the coast socialite and man to Koncthi Fouta (Atlantic Ocean) in the South, to Cabinda (Republic of Angola).

The Figures I, II, III and IV, below show the plant, fruit and almonds nuts Hyphaene guineensis.

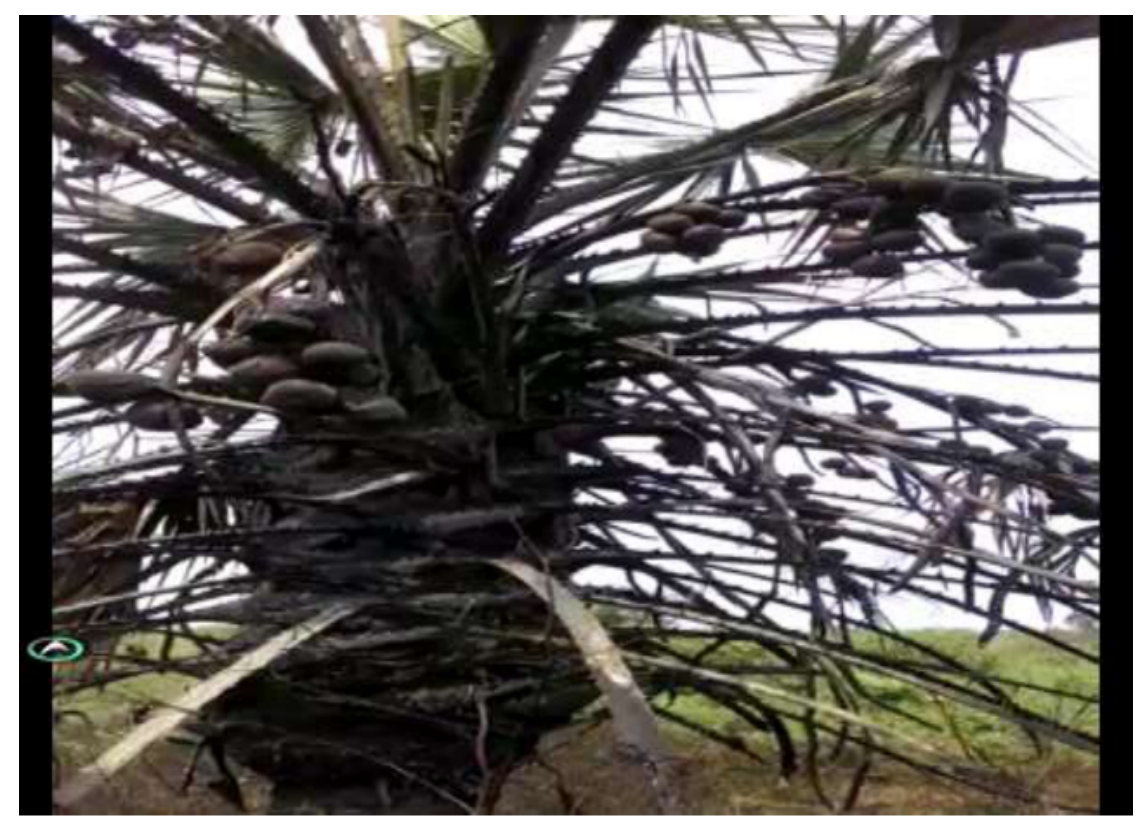

Figure 1 Hyphaene guineensis showing fruit plant 
J.P.L. Ossoko, J. Enzonga Yoca, Y.Okandza, M.G. Dzondo, M.D. Mvoula Tsieri

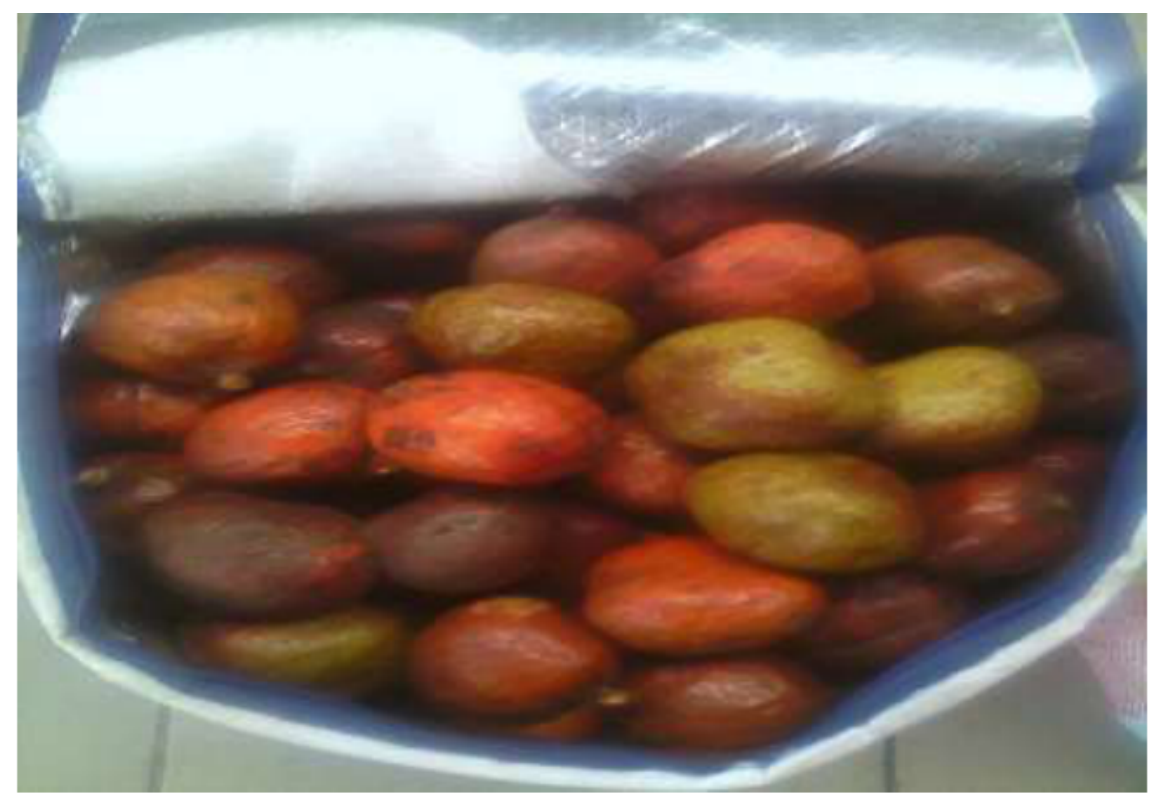

Figure 2 Mature Fruits of Hyphaene guineensis

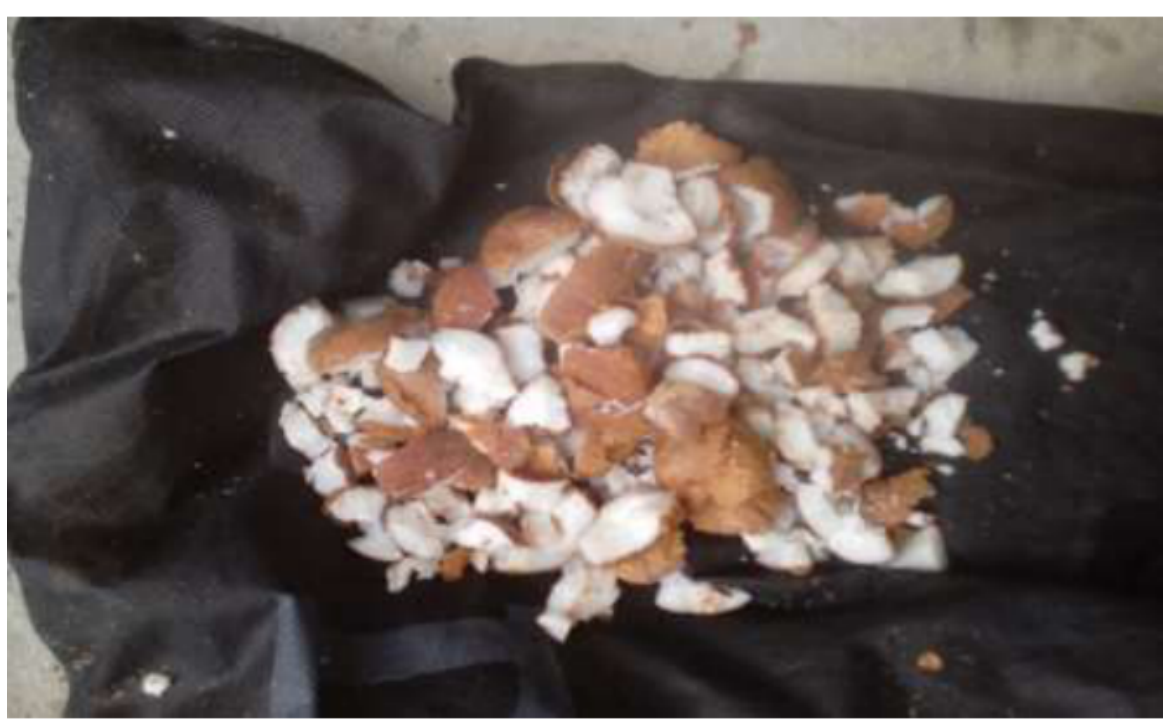

Figure 3 Hyphaeneguineensis fresh almonds

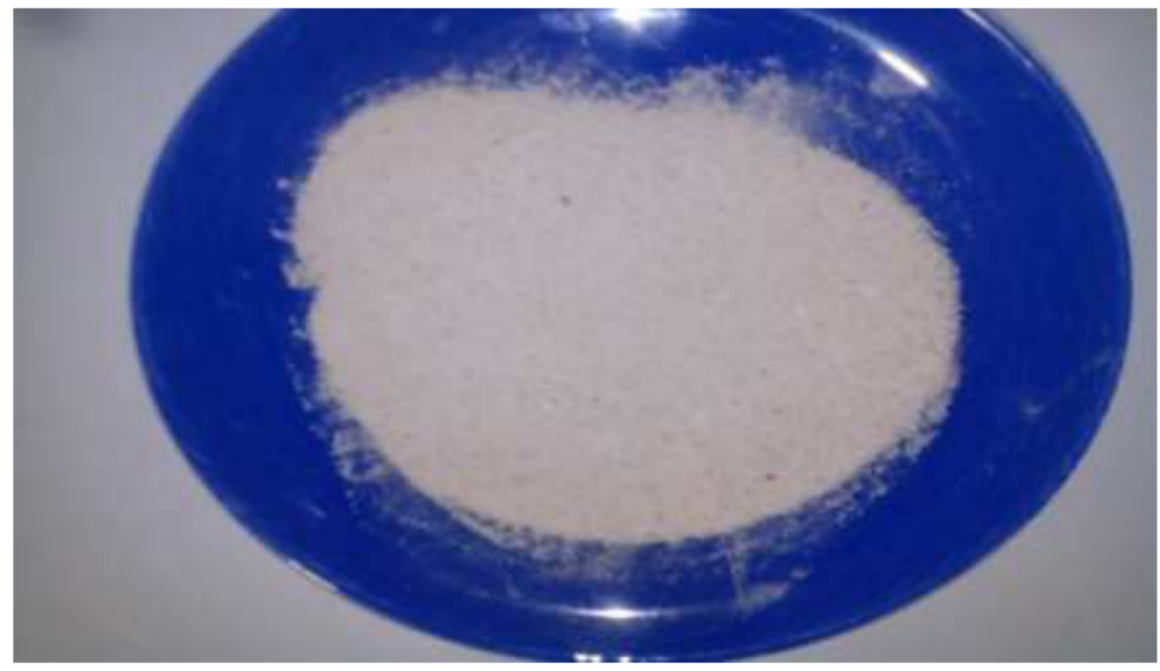

Figure 4 Crushed dried almonds from Hyphaeneguineensis 
Biochemical Characterization of the Almonds of Hyphaene Guineensis of Prefecture of Pointe

Noire in the Republic of Congo

\subsection{Methods}

We have described the methods to determine the length, diameter and mass of fruits and nuts, moisture, lipids, protein levels, ash rate and major minerals, carbohydrates and fiber content.

\subsubsection{Determination of the length, diameter and the Masses of fruit and the nuts $(L, D, M)$}

We used the foot slide to measure the length and diameter of the fruits and nuts and we used a scale precision to determine the mass of each fruit and nuts. We used for each sample, 50 fruit and 50 nuts.

\subsubsection{Determination of moisture (H)}

The humidity level was determined according to the $A O A C$ method (2005) [8]. $2 \mathrm{~g}$ of crushed after almonds grating is placed in a previously weighed capsule and put the oven (Memmert, Germany) at $70^{\circ} \mathrm{C}$ until the mass becomes constant.

\subsubsection{Determination of the content $(C)$ raw ash and major mineral}

$2 \mathrm{~g}$ of grated almonds cakes have been used for the determination of the rate of ashes according to gravimetric method [8]. The incineration of the samples is performed in an oven mitten at $550^{\circ} \mathrm{C}$ for 6 hours. The rate of ash after incineration is calculated.

Mineral levels are measured by atomic absorption spectrophotometry (Perkin-Elmer1100) on ash obtained after mineralization. Prior to dosing, the ashes are diluted in a solution containing $10 \%$ as corrector of interactions lanthanum chloride (concentration: $116 \mathrm{LaCl} 3 \mathrm{~g}$ in 11 of $\mathrm{HCl}$ concentrated diluted to one-quarter).

\subsubsection{Determination of the rate of fat (MG)}

The lipids in $5 \mathrm{~g}$ of grated and dried almonds were extracted using Soxhlet (NF ISO 8262 - 3, 2006) per $200 \mathrm{~mL}$ of hexane for 6 hours. The excess of solvent is evaporated to the rotavapor (IKA HB 10 basic).

\subsubsection{Determination of the rate of protein $(P)$}

About $0.1 \mathrm{~g}$ of grated almonds are used to determine the rate of crude protein from the determination of total nitrogen by the method of Kjeldhal [8]. Protein was obtained by multiplying the total nitrogen by a convention factor 6.25 .

\subsubsection{Determination of the rate of total carbohydrate $(G)$}

Carbohydrate $(\mathrm{G})$ was estimated by the difference method [8]. According to this method, it was calculated by subtracting from 100 , the sum of moisture $(\mathrm{H})$, of the FAT $(\mathrm{MG})$, protein $(\mathrm{P})$ and ash $(\mathrm{C})$ contained in the sample.

\subsubsection{Determination of the rate of crude fiber (FB)}

Levels in raw fibers of the samples are determined by the method of Weende [9]. To do this, 1 g grated almonds (M) is brought to a boil in $50 \mathrm{ml}$ of sulfuric acid $(0.25 \mathrm{~N})$ and then $50 \mathrm{ml}$ of soda $(0.31 \mathrm{~N})$ for $1 \mathrm{~h}$. The resulting residue is dried at $105^{\circ} \mathrm{C}$ for $8 \mathrm{~h}$ and then cremated at $550{ }^{\circ} \mathrm{C}$ for $3 \mathrm{~h}$

\subsubsection{Determination of the energy value (EV)}

The total energy value was calculated according to the method of Manzi (1999) cited by Diallo Koffi and al. [10]

The energy value is determined by using the formula above - after: 
$\mathrm{VE}(\mathrm{kcal} / 100 \mathrm{~g})=(\mathrm{CHO} \times 4)+(\mathrm{CL} \times 9)+(\mathrm{CP} \times 4)$ with $\mathrm{CHO}=\%$ of carbohydrates. $\mathrm{CL}=\%$ of lipids and $\mathrm{CP}=\%$ protein.

\section{RESULTS AND DISCUSSION}

\subsection{Length, diameter, and Masses of fruit and nuts}

The results obtained for each sample are as follows:

Diameter of the fruits of 4, 654 $\pm 0,30-4,67 \pm 0,30 \mathrm{~cm}$;

Mass of fruit: $87,88 \pm 0,40 \mathrm{~g}$.

Diameter of nuts 3, $02 \pm 0,30$ to $3,24 \pm 0,30 \mathrm{~cm}$

Average mass of nuts: $52,60 \pm 0,40 \mathrm{~g}$

The results obtained with the Palm (Borassus aethiopum) are:

Diameter of the fruits of $11,7 \pm 0,30$ to $11,9 \pm 0,30 \mathrm{~cm}$

Mass of fruit: $1,42 \pm 0,15 \mathrm{Kg}$

Diameter of nuts $5,4 \pm 0,20$ to $6.4 \pm 0,20 \mathrm{~cm}$

Average mass of nuts: 196, 75 $\pm 0,35 \mathrm{~g}$.

Hyphaene guineensis fruits are small compared to those of Borassus aethiopum is and their fruit and almonds.

\subsection{Humidity level}

The different tests for the moisture content obtaining gave an average value of $37,32 \%$ on our fresh almonds. This high content is explained by the fact that the almonds used for extraction have been freshly harvested. So for a better conservation, the kernels must be dried beforehand. This humidity is less than 56, 33\% [11] obtained on the almonds of Borassus aethiopum and also very low compared to the Cocos nucifera (94.45\%) [12]; which allows to conclude (guineensis Hyphaene fresh almonds) studied are less hydrated than Cocos nucifera and therefore keeps a little better than the last.

This value $37,32 \%$ is very high as those obtained by various authors on peanuts: $7.48 \%$ $[13,14]$ on seeds (groundnut, groundnut and groundnut roasted sun-dried raw); 7.54\% [15] on the varieties Sinkarzie, F-mix, JL 24, and Manipintar ; 4, 12-4, 75\% [16] on day 93, Rio Balsas, Ocozocuautla, varieties Tlaxmalac, Gerardo Uribe, Ranferi Diaz, A-18 and RF-214 in Mexico; 5, 55-6, 05\% [17] on a variety of peanut in Sri Lanka after treatments of organic fertilizers; 7,18\% [18] on a variety of peanut of Nigeria and 5.8\% [19] on another variety of peanut in Nigeria this is however lower than the fresh almonds of the Palm (Borassus aethiopum) which is $45 \%$. This water content is not normal for a good preservation of seeds (the conservation of seed water content ranges 10 and 14\%).

\subsection{Lipid content}

The almonds of Hyphaene guineensis Soxhlet extraction gives an average fat content of $13,51 \%$, very low value compared to that of Cocos nucifera, which is over $60 \%$ almonds (www.information) nutritionnelle.fr). This resulting content is less than the values of $46,10 \%$ [14], 40 to $42 \%$ [20], 46\% [21] and 39,30\% [18]. Some authors [16], by studying the chemical properties of eight varieties of peanuts grown in the Mexico obtained oil seeds ranging from 37.9 to 56.3 percent levels.

This value of $13,51 \%$ shows that Hyphaene guineensis almonds are also a good source of fat and can be used industrially in the production of oil. However, this value is very small compared to the values obtained by some authors [22], values ranging from 68.88 to $72.40 \%$, 
Biochemical Characterization of the Almonds of Hyphaene Guineensis of Prefecture of Pointe

Noire in the Republic of Congo

working on hybrids of (Cocos nucifera L.) From PB121 of Vitro culture according to the stages of maturity and the duration of storage of nuts: Hyphaene guineensis is less rich in fat compared to the coconut almonds studied these authors.

\subsection{Protein content}

The average protein content has been determined from 6 tests. The result is a value of 5 , $64 \pm 0,50 \%$, low value compared to almonds of coconut palm (Cocos nucifera) which have a protein content of 13\% (www.information nutritionnelle.fr). Some authors [22], working on hybrids of (Cocos nucifera L.) From PB121 of Vitro culture according to the stages of maturity and the duration of storage of nuts have obtained values from 22,44 to $28,03 \%$ : Hyphaene guineensis is less rich in protein compared to the coconut almonds studied these authors.

This value of 5, $64 \%$ is also very low compared with the values obtained by some authors working on some varieties of peanuts: $38,61 \%$ [19]; 19,81\% [18]; 24.70\% [13]. 27, 54-32, 85\% [16]; 23, 62-28, 88\% [15]. 32.64\% [23]. So arguably Hyphaene guineensis is not proteagineuse. Hyphaene guineensis almonds are not a good source of protein.

Hyphaene guineensis almonds are less rich in protein than seeds of Voandzou (Vigna subterranea (1.) grown in Côte d'Ivoire with a rate ranging from 14,61 to 20,74\% [10].)

\subsection{Rate of ash and minerals}

The different tests for the analysis of the rate of ash gave an average value of $2,35 \pm 0,50 \%$, comparable to that of the kernels of Cocos nucifera, which hovers around $2.5 \%$. What indicates that Hyphaene guineensis almonds contain a significant amount of minerals: so it is a good source of minerals.

This value of $2,35 \pm 0,50 \%$ is very low compared with 5,44 to $6.74 \%$, [22] values obtained on hybrids of (Cocos nucifera L.) From PB121 to Vitroculture according to the stages of maturity and the duration of storage of nuts: Hyphaene guineensis is less rich in minerals that the coconut almonds studied by those authors.

This value is higher than those whose values vary from 1.38 to 1.48 percent on the seeds of peanut $[13,14]$. It is substantially equal to those whose values ranging from 2.45 to $2.96 \%$ also on peanuts [15]; some authors [19] Meanwhile achieved a value on peanuts of: $3.8 \%$, which is higher than the rate from the ashes of our sample of almonds of Hyphaene guineensis. Peanut 'Manga "has a rate of 5.68\% ash [23], very high value than our almonds studied here.

Hyphaene guineensis contains many mineral ions in significant amounts.

So we researched phosphorus, iron, calcium and magnesium in the obtained ash and the result: phosphorus: $0.18 \%$, iron: $0.06 \%$, Calcium: $0.44 \%$ and Magnesium: $0.65 \%$. This result shows that there are still minerals to determine in these ashes.

These minerals are essential to the proper functioning of the body.

\subsection{Rate of glucide}

The levels of carbohydrates in varieties of peanut: $1.81 \%$ [19]; 17.41\% [13, 14]. 11, 54-19, $65 \%$ [15] and $17.56 \%$ [23], are well below that of Hyphaene guineensis which is of $41,18 \%$ $0.42 \%$ of free sugars identified by spectrometry. This $41,18 \%$ value is far greater than the values ranging from 2.44 to 2.94\% [22]. Hyphaene guineensis almonds are a good source of carbohydrates it takes to operate in the food and feed 


\subsection{Rate of fiber}

The rate of fiber is $10,85 \%$, a value very close to $11.2 \%$ [11] obtained on Borassus aethiopum. Hyphaene guineensis almonds are a good source of fiber that must be exploited in human and animal food.

\subsection{Energy value}

The resulting energy is $308,87 \mathrm{Kcal} / 100 \mathrm{~g}$. This value is less than those obtained on the seeds of seven cultivars of voandzou [Vigna subterranea (1.) Verdc. Fabaceae] grown in Côte d'Ivoire, values ranging from 370,02 to $388.8 \mathrm{Kcal} / 100 \mathrm{~g}$ [10]. This value of 308, $87 \mathrm{Kcal} /$ $100 \mathrm{~g}$ is significant and is a good source of energy and nutrients that must operate wisely in the diet of the vulnerable population of Hyphaene guineensis .

\section{CONCLUSION}

Dans le cadre de la valorisation des amandes, Hyphaene guineensis qui a fait l'objet de notre étude est l'une de nombreuses variétés de palmiers qui existent dans notre pays et qui n'a jamais fait l'objet d'une étude scientifique.

Hyphaene guineensis is a Palm in the coast region with almonds are at Cocos nucifera of white color, rich in lipids, in carbohydrates more fiber and less rich in protein. Their fruits are small compared to those of Borassus aethiopum. Almonds are also a good source of minerals ions because their high ash content. This takes us to say that these almonds have a good food value.

This work is far from over. The study of food quality oil is to continue (the determination of the composition in fatty acids, glycerides, phospholipids, ceramides, and sphingomyelin, the position of fatty acids on triglycerides, on phospholipids and the) composition of the unsaponifiable).

The ash content is high, it is important that a follow-up study be carried out to determine the other mineral elements which are not studied so far.

This work should be completed by making a thorough study of the protein fraction of these almonds. Thus, it would enhance oilcake deshuiles these almonds (quite high in protein and rich in fibers and carbohydrates) in the flour food manufacturing human and feed.

\section{REFERENCES}

[1] Silou T., Biyoko S., Heron S., Tchapla A., Maloumbi M.G, Caractéristiques physicochimiques et potentialités technologiques des amandes de Irvingia gabonensis. La Rivista italiana dell grasse (LXXXI), 2004, pp 49-56.

[2] Binaki AF, Kama Niamayoua R, Enzonga Yoca J, Loumouamou BW, Mvoula Tsieri M, Silou $\mathrm{T}$, Caractérisation Physico chimique de la matière grasse de Anisophyllea quangensis Ex Henriq du Bassin du Congo. Journal of Animal and Plant Sciences, 20, Issue1, 2013, 30793092.

[3] Kapseu C, Production, Analyse et Application des huiles végétales Africaines. OCL 16, 2009, pp 215-229.

[4] Loumouamou B, Contribution à la valorisation des oléagineux du genre Irvingia du Bassin du Congo. Composition chimique et potentialités technologiques des amandes, Thèse de Doctorat de l’Université Marien Ngouabi, Brazzaville, 2012, 128p.

[5] Womeni HM, Tiencheu B, Tenyang N, Tchouanguep Mbiapo F, Kapseu C, Linder M, Fanni J., Extraction of palm kernel oil in Cameroon: effets or kernels driying on oil quality. J. Food Technol. 8, 2011, pp 1-7. 
Biochemical Characterization of the Almonds of Hyphaene Guineensis of Prefecture of Pointe Noire in the Republic of Congo

[6] Attibayeba, Ngatsoué L., Massamba D., Makoundou B, Variation des lipides dans les amandes au cours de la croissance et de la maturation des fruits de Grewia coriaceae Mast (Tiliaceae), La Rivista Italliana delle sostanse grasse LXXXIII, 2010, pp 58-60.

[7] Silou T, Corps gras non conventionnels du Bassin du Congo: Caractérisation, biodiversité et qualité. $O C L$. 21(2) D209, 2014, 15 p.

[8] $A O A C$, Official method of analysis of the Association of official Analytical Chemist, 5th ad. AOAC Press, Arlington, Virginia, USA, 2005

[9] Wolff J. P, Manuel d'analyse des corps gras; Azoulay éd., Paris (France), 1968, 519 p.

[10] Diallo Koffi Séraphin, Koné Kisselmina Youssouf, Soro Doudjo, Assidjo Nogbou Emmanuel, Yao Kouassi Benjamin, Gnakri Dago, 2015. Caractérisation Biochimique et Fonctionnelle des Graines de Sept Cultivars de Voandzou [Vigna Subterranea (1.) Verdc. Fabaceae] Cultivés en Côte d'Ivoire. European Scientific Journal. vol.11, No.27. 2-17 p.

[11] Kabiru Jega Umara, Bello Mani Abdullahib, Badaru Muhammadc, Sirajo Muhammadd, Lawal Gusau Hassane, Nasiru Alhaji Sanif, Nutritional and Antinutritional Profile of Borassus aethiopum Mart (African Palmyra Palm) Shoots. International Journal of Sciences: Basic and Applied Research (IJSBAR) ISSN 2307-4531 (Print \& Online), 2015, 1-11 p.

[12] Jean WH, Yong, Liwa Ge, Yan Fei Ng and Swe Ngin Tan, The Chemical Composition and Biological of Coconut (Cocos nucifera) Water, Molecules 14, 2009, pp 5144-5164.

[13] Ayoola P.B. and Adeyeye A, Effect of Heating on Chemical Composition and PhysicoChemical Properties of Arachis hypogea (Groundnut) Seed Flour and Oil. Pakistan Journal of Nutrition 9 (8), 2010, pp 751-754

[14] Ayoola P.B., Adeyeye A. and Onawumi O.O, Chemical evaluation of food value of groundnut (Arachis hypogaea) seeds. Am. J. Food. Nutr, 2(3), 2012, pp 55-57.

[15] Eshun G., Adu Amankwah E., and Barimah J, Nutrients content and lipid characterization of seed pastes of four selected peanut (Arachis hypogaea) varieties from Ghana. Glob. J. Food Sci. Technol. ISSN: $x x x x-x x x x .1$ (1), 2013, pp 108-114.

[16] Mora-Escobedo R., Hermandez-Luna P., Joaquin-Torres I.C., Ortiz-Moreno A. and RoblesRamirez M. Del C, Physicochemical properties and fatty acid profile of eight peanut varieties grown in Mexico. CyTA-Journal of Food, 13, 2, 2015, pp 300-304.

[17] Brintha I., Mahendran T. and Seran TH, Nutritional Composition and Storage Stability of Groundnut (Arachis hypogaea L.) Seeds Cultivated with Organic Fertilizers. Tropical Agricultural Research and Extension 17(2), 2014

[18] Adegoke Bosede M., Shittu Suraj A., Raimi Monsurat M., Oyetade Olumide A., Oyekanmi Adeyinka M, Effect of Traditional Processing Methods on the Protein and Lipid Content of Arachis hypogaea (Groundnut). International Journal of Scientific and Research Publications, 4, Issue 5, 2014, 3 p.

[19] Atasie V.N., Akinhanmi T.F. and Ojiodu C.C, Proximate Analysis and Physico-chemical Properties of Groundnut (Arachis hypogaea L.). Pakistan Journal of Nutrition 8 (2), 2009, pp 194-197.

[20] Mustapha S., Mohammed U.M., Adeosun N.O., Mathew T.J., Muhammed S.S., Ibn-Aliyu A. , American Journal of Food Science and Technology, 3, 5, 2015, pp 126-131.

[21] Olayinka B.U., Yusuf B.T., Etejere E.O, Growth, Yield and Proximate Composition of Groundnut (Arachis hypogaea L.) as Influenced by Land Preparation Methods. Not Sci Biol, 7(2), 2015, pp 227-231.

[22] Deffan Zranseu A. B., Konan Jean Louis K., Assa Ablan R. et Kouame Lucien P, Caractérisation Physico-Chimique de l'Amande d'Hybride de Cocotier (Cocos nucifera L.) PB121 issus de Vitro culture selon les Stades de Maturité et la Durée de Stockage des noix, 2011

[23] Ossoko J. P. L., Valeur Nutritionnelle des Arachides (Arachis hypogaea L.) de «MANGA» : Etude de leurs Propriétés Lipidiques et Allergéniques. Thèse de Doctorat Unique, 2017, 142 p. 